\title{
Effect of incorporation of rice, potato and mung flour on the physical properties of composite flour biscuits
}

\author{
Suresh Chandra ${ }^{1 *}$, Samsher, ${ }^{1}$ Pankaj Kumar, ${ }^{2}$ Vaishali $^{3}$ and Durvesh Kumari ${ }^{4}$ \\ ${ }^{1}$ Department of Agric. Engineering and Food Technology, SVPUAT, Meerut-250110 (UP) \\ ${ }^{2}$ Department of Agriculture Biotechnology, SVPUAT, Meerut-250110 (UP) \\ ${ }^{3}$ Department of Biochemistry and Physiology, SVPUAT, Meerut-250110 (UP) \\ ${ }^{4}$ Sri Vankateswara University, Gajraula (UP) \\ *Corresponding author: chandra21778@yahoo.co.in
}

\begin{abstract}
The present work was conducted to develop biscuits from the composite flours incorporating wheat flour with rice, green gram and potato flour. Composite flours were prepared by blending wheat flour with rice flour, mung flour and potato flour in ratios of 100:0:0:0 $\left(\mathrm{W}_{100}\right)$, 85:5:5:5 (W $\left.\mathrm{W}_{85}\right)$, 70:10:10:10 $\left(\mathrm{W}_{70}\right)$ and 55:15:15:15 $\left(\mathrm{W}_{55}\right)$, respectively. The protein, fat, ash and $\mathrm{pH}$ increased with increasing proportion of rice, green gram and potato flour from 5 to 15 percent while acidity was decreased simultaneously. In case of individual flour, wheat flour was found highest moisture (13.284\%), green gram for protein $(21.038 \%)$ and fat $(1.226 \%)$ and potato for ash content $(1.092 \%)$. The biscuits were prepared from wheat flour $\left(\mathrm{W}_{100}\right)$ and three composite flours $\left(\mathrm{W}_{85}, \mathrm{~W}_{70}\right.$, and $\left.\mathrm{W}_{55}\right)$. The physical properties of these biscuits were observed. The mass, diameter, thickness and bulk densities decreased whereas spread ratio and percent spread increased with increasing the level of incorporation of other flours.
\end{abstract}

Keywords: Bulk density, browning index, composite flour, spread ratio, percent spread.

Many people in the less developed countries are faced with the problems of malnutrition due to deficiencies of protein and calories. The use of protein calorie source of vegetable origin has been proposed as a possible solution to this problem. Proteins which have adequate nutritional value and form part of the regular diet of the people would be possible candidates for this purpose (FAO, 1970). The wide prevalence of proteincalories malnutrition in developing countries is of great importance not only to food scientists, nutritionists or agricultural scientists but also for concerned governments as well (Olsen, 1975). The continuous increase in population and inadequate supply of protein has inadvertently increased the occurrence of malnutrition in developing countries (Siddhuraju, 1996). Recent studies have shown that malnutrition among children in developing countries is mainly due to the consumption of cereal based porridge which is bulky, low in energy and density and high in antinutrients (Michaelsen and Henrik, 1998). Plant protein products are gaining increased interest as ingredients in food systems throughout many parts of the world; the success of utilizing plant proteins as additives depends greatly upon the favourable characteristics that they impart to foods. In the developed countries, plant proteins are now either regarded as versatile functional ingredients or as biologically active components more than as essential nutrients (Marcello and Gius, 1997).

The partial replacement of animal foods with legumes has been shown to improve nutritional status (Guillion and Champ, 1996) due to lower cholesterol level in plant foods. Also, plant food diets increase the level of fibre intake which reduces the risk of bowel diseases, including cancer and also reduction in osteoporosis incidence (Sirtori and Lovati, 2001). This evolution towards health and functionality is mainly driven by the demands of consumers and health professionals. In food products manufacturing, it is important to balance the quality and quantity of protein keeping in view the nutritional status of populations (Hung and Zayas, 1991). The total protein content and the total essential amino acids are important factors from nutritional view point; essential amino acids should be supplied in adequate amounts in the daily diet 
(Anjum et al., 2005). Cereal proteins are deficient in few essential amino acids like lysine and tryptophan but these deficiencies are mainly related to endosperm portion of the kernel (Myer et al.,1996). Wheat flour substitution with legume could contribute the increasing demands for protein and energy rich food preparations (Iqbal et al., 2006).

Composite flours are quite different from the ready-mixed flours familiar to millers and bakers. Whereas ready-mixed flour contains all the nonperishable constituents of the recipe for a certain baked products, composite flours are only a mixture of different vegetable flours rich in starch or protein with or without wheat flour for certain groups of bakery products. The use of composite flours with or without wheat gives rise to technical problems in the production of baked goods. Composite flour is a binary or ternary mixture of wheat flour with flour from other crops (Shittu et al., 2007). Composite flour is considered advantageous in developing countries as it reduced the importation of wheat flour and encourages the use of locally grown crops as flour (Hugo et al., 2000).

From the bakers point of view, the most important component of the wheat flour is the protein of the gluten, which plays a decisive role in dough formation, gas retention and the structure of the crumb. If flour mixtures containing little or no wheat are used, certain tricks have to be employed to achieve properly leavened products in the end. The cereal based products made from composite flours are widely accepted and have been commercialized in many parts of the world to improve the nutritional and other quality parameters of end products. Cereal grains and legumes play significant role in supplying the nutrients, as well as providing over $70 \%$ of the daily energy requirements. The composite flour technology refers to the process of mixing wheat flour with cereals and legumes to make use of local raw material to produce high quality food products in an economical way. The plant protein foods contribute $\approx 65 \%$ of the per capita supply of protein on a worldwide basis. The mixtures of plant proteins can serve as a complete and well-balanced source of amino acids for meeting human physiological requirements.

Biscuit is most popular bakery product worldwide. They are high in carbohydrates, fat and calorie but low in fiber, vitamin, and mineral which make it unhealthy for daily use. Because of its acceptability in all age group, longer self-life, better taste and its position as snacks it is consider as a good product of for protein fortification and other nutritional improvement. The main ingredients of any bakery products is wheat, which is having deficiency of essential amino acid lysine (Bakle and Vickers, 2007; Dewettinck et al., 2008; Jideani and Onwubali, 2009). Biscuits are consumed by a wide range of population due to their ready to eat nature, good nutritional quality, wide range of varieties, affordable cost, long shelf life, easy to availability (Laguna et al., 2011).The biscuit industry is the largest constituent of food processing industry. In India the organized sector produces around $60 \%$ of the total production and the remaining $40 \%$ being contributed by the unorganized bakeries. The industry consists of two large scale manufacturers, around 60 medium scale brands and small scale units ranging up to 4500 units in the country. The unorganized sector is estimated to have approximately 30,000 small and tiny bakeries across in the country. There is a great scope for biscuit industry in India as the demand for biscuit is increasing 7\% per annum which may increase further with globalization of economy and urbanization, but annual production growth rate is approximately $2-4 \%$ per annum. Though India is considered as the third largest producer of biscuits after USA and China, the export of biscuits is approximately $17-20 \%$ of the total annual production. The per capita consumption of biscuits in our country is only 2.1 $\mathrm{Kg}$ /year.

Therefore, it has become imperative to develop cultivars for biscuit. The quality of the flour for biscuit making depends on the texture and composition of the kernel. Soft texture of grain, low protein content and weak gluten strength are primary requirements of biscuit making quality. Mixture of high protein cereal like corn, legumes such as soybean and green gram for the production of highly nutritious biscuits, snacks etc. (Mishra et al., 1991). Earlier work on the development of protein-enriched biscuits involved addition of mustard protein concentrate and cotton seed protein isolate (Rajput et al., 1988), mustard flour (Tyagi et al.,2007), Soybean (Singh et al., 2000; Gandhi et al., 2001), sorghum (Rao and Shurpalekar, 1976; Rao et al., 1984), fenugreek flour (Hooda and Jood, 2005), skim milk powder (Rao et al., 1984), sodium caseinate (Bassi and De, 1973; Gallagher et al., 2005) and Whey Protein Concentrate (Gallagher et al., 2005). The utilization of legume flour as a source of protein in bakery products 
(Eneche, 1999; Hegazy and Faheid, 1999; Patel and Rao, 1995), cereal with milk or legume flour (Adeyemi et al., 1989), defatted soy flour (Singh et al., 1996), chickpea and broad bean flour as well as isolated soy protein (Rababah et al., 2006) has been reported previously. Chandra et al., (2014) were prepared the composite flour made from wheat flour incorporating with rice flour, green gram flour and potato flour for the development of biscuits.

Physical properties are considered to be important in problems associated with design of specific machine or analysis of the behavior of the products in baking, handling, packaging, processing and storage of materials. However, no paper till date gave emphasis on the effect of incorporation of different flours with wheat flour on the physical properties of the biscuits. Seevaratnam et al., (2012) studied on the preparation of biscuits incorporated with potato flour. The physical characteristics of biscuits like bulk density, spread ratio and spread factor were decreased significantly with increasing level of potato flour replacement, but volume of biscuits was increased significantly and thickness increased slightly.

According to Khaliduzzunman et al., (2010), the thickness of biscuits increased slightly with increasing level of potato flour up to 25 percent. On other hand, diameter of biscuits and spread ratio was decreased as substitution level of potato flour increased in the baked samples and this may be due to higher water holding capacity. The intention of this research work is to be study the proximate analysis of the flours and to emphasis the effect of rice, green gram and potato flour incorporating with wheat flour on the physical properties (mass, diameter, thickness, spread ratio, percent spread and bulk density) of the prepared fresh biscuits.

\section{Material and Methods}

The research work was investigated at Food Processing Unit of the Department of Agricultural Engineering and Food Technology, Sardar Vallabhbhai Patel University of Agriculture and Technology, Meerut (India). Raw materials viz., wheat flour (maida or refined flour), rice flour, mung flour, potato, chemicals and glass-wares, etc. were procured from the local market for the present study.
Development of composite flours: The composite flours were prepared by blending wheat flour with rice flour, mung flour and potato flour in ratios of 100:0:0:0 $\left(\mathrm{W}_{100}\right), \quad 85: 5: 5: 5 \quad\left(\mathrm{~W}_{85}\right), \quad 70: 10: 10: 10 \quad\left(\mathrm{~W}_{70}\right)$ and 55:15:15:15 (W55), respectively. After thorough blending the flours were sieved to get the uniform dispersion of the other flour's particles with that of wheat flour. These blended flours were used to develop the biscuits and packaged in suitable packaging materials for storage and further findings.

Proximate analysis of flours: The moisture, protein, fat, ash content of all types of flours was analytically estimated by the methods as recommended by AOAC (2000). The $\mathrm{pH}$, acidity and browning index (optical density) was determined by using the method as recommended by Ranganna (2001).

Physical Properties of Biscuits: Mass of biscuits (g) was measured as average of values of five individual biscuits with the help of digital electronic weighing balance. The diameter of biscuits was measured by laying five biscuits edge to edge with the help of a scale rotating those at $90^{\circ}$ and again measuring the diameter of five biscuits $(\mathrm{cm})$ and then taking mean value. Thickness was measured by stacking five biscuits on a top of each other and taking mean value of thickness $(\mathrm{cm})$. Spread ratio was calculated by dividing the mean value of diameter by mean value of thickness of biscuits. Percent spread was calculated by dividing the spread ratio of composite biscuit with spread ratio of control biscuits and multiplying with 100 . The bulk density was determined according to the method described by Okaka and Potter (1977) with slight modification. Fifty gram ground sample of biscuits was put into a $100 \mathrm{ml}$ graduated cylinder. The cylinder was tapped 40-50 times and the bulk density was calculated as weight per unit volume of samples.

\section{Results and Discussion}

The present study was undertaken the wheat flour (refined flour) was blended with rice flour, green gram flour and potato flour in various combinations to prepare composite flours and biscuits. The proximate analysis of composite as well as other flours was determined using standard procedures. The physical properties of biscuits were also analyzed just after preparation. Data were statistically analyzed using OPSTAT statistics program. 


\section{Proximate analysis of flours}

The effects of various proportions of wheat flour, rice flour, green gram flour and potato flour on proximate composition of composite flours are discussed in the following sections. The proximate composition of wheat flour $\left(\mathrm{W}_{100}\right)$, rice flour $\left(\mathrm{R}_{100}\right)$, green gram flour $\left(\mathrm{G}_{100}\right)$, potato flour $\left(\mathrm{P}_{100}\right)$ and composite flours $\left(\mathrm{W}_{85}, \mathrm{~W}_{70}\right.$ and $\left.\mathrm{W}_{55}\right)$ were analyzed and data presented in Table 1.

Effect on moisture content: The moisture content for different flours is presented in Table 1 which ranged from $8.052 \%$ to $13.284 \%$ depending upon the blending ratio. The highest value was observed for wheat flour (13.284\%) and the lowest for green gram flour $(8.052 \%)$. The moisture content of other flours viz., rice flour $(11.222 \%)$, potato flour $(9.604 \%)$, and composite flours i.e. $\mathrm{W}_{85}(11.670 \%), \mathrm{W}_{70}(11.342 \%)$ and $\mathrm{W}_{55}(10.928 \%)$ were also determined. From the Table1, it is clear that the moisture content of composite flours decreased with increase in proportions of other flours. The moisture content of composite flour was highly affected by blending of green gram and potato flours. The highest moisture content was observed for $\mathrm{W}_{85}(11.67 \%)$ and lowest for $\mathrm{W}_{55}(10.928$ $\%)$ in the composite flours.

The study revealed that moisture content of composite flours decreased with decrease in proportions of wheat flour from $100 \%$ to $55 \%$. Similar trends were reported by Kaushal et al., (2012). They used the blends of taro, rice and pigeon pea flour which resulted in reduction of moisture content of composite flours. From Table 1, it is doubtless that moisture content of wheat flour was found to be significant for $\mathrm{W}_{85}, \mathrm{~W}_{55}$ and potato flour $\left(\mathrm{P}_{100}\right)$ at $\mathrm{p} \leq 0.05$ level of significance. The statistical constants like $\mathrm{CD}_{0.05}$, SE (d), SE (m), CV and Coefficient of determination $\left(\mathrm{R}^{2)}\right.$ of the flours were calculated and obtained as $0.831,0.400,0.283,5.814$, and 0.738 , respectively.

Effect on protein: The protein content ranged between 2.138 to 21.038 percent depending upon type of flours. The highest protein was estimated for green gram flour (21.038\%) followed by $\mathrm{W}_{55}(16.844 \%), \mathrm{W}_{70}(15.152 \%)$, $\mathrm{W}_{85}(13.452 \%)$, rice flour $(10.058 \%)$, wheat flour $(9.646 \%)$ and potato flour $(2.138 \%)$. It was observed that the composite flour resulted higher values of protein content as compared to wheat flour. The protein of composite flours increased with increase in blending ratio of rice, green gram and potato flour. It depends on mainly increasing incorporation ratio of green gram flour in wheat flour. Thus, the amount of green gram flour had highly affected the level of protein content of composite flours. It was also indicated that protein content of composite flours increased with decrease in blending ratio of wheat flour. The protein content for all types of flours was found to be significant at $\mathrm{p} \leq 0.05$ level of significance. The statistical analysis revealed that the protein content of composite flours increased significantly with increase in incorporation ratio of other flours except wheat flour. The statistical analysis parameters i.e. $\mathrm{CD}_{0.05}, \mathrm{SE}(\mathrm{d}), \mathrm{SE}(\mathrm{m}), \mathrm{CV}$ and $\mathrm{R}^{2}$ of the flours were calculated and obtained as $0.659,0.318$, $0.225,3.979$, and 0.025 , respectively.

Similar trends were found by Akubor (2007) and reported that protein content of the blends varied from 12.2 to $35.0 \%$ as compared to 7.5 to $38.2 \%$ in maize and soy flour, respectively. The present study revealed that protein content of composite flours were found to be higher as compared to wheat flour but lower than green gram flour. Kaushal et al., (2012) reported that an increase in the amount of taro flour resulted decrease in the protein content of blends. According to Njintang et al., (2007), as a result of the low levels of protein in taro flour, their incorporation into wheat flour is expected to reduce the protein content of composite flours. In present study, increasing the proportion of green gram and decreasing the proportion of other flours affected the protein content of composite flours.

Effect on Fat: The fat content in flours varied from 0.334 to $1.392 \%$ shows in Table 1 . The highest fat was observed highest for $\mathrm{W}_{55}$ flour $(1.392 \%)$ followed by $\mathrm{W}_{70}(1.344 \%), \mathrm{W}_{85}(1.214 \%)$, green gram flour $(1.226 \%)$, rice flour $(0.98 \%)$, wheat flour $(0.832 \%)$ and potato flour $(0.334 \%)$. Table 1 depicted that fat content of composite flours increased with incorporation ratio of other flours except wheat flour. The fat content increased with decrease in the proportion of wheat flour. The fat content of flours were found to be significant at $\mathrm{p} \leq 0.05$ level of significance to each other. The fat content of composite flours increased significantly with increase in incorporation ratio of rice, green gram and potato flour with wheat flour. The fat content of composite flours was found to be higher as compared to wheat flour. The statistical analysis for fat content i.e. 
$\mathrm{CD}_{0.05}$, SE (d), SE (m), CV and $\mathrm{R}^{2}$ were calculated and obtained as $0.051,0.024,0.017,3.684$, and 0.145 , respectively.

Effect on Ash: FromTable 1, the results revealed that the rice flour $\left(\mathrm{R}_{100}\right)$ had lowest value of ash content $(0.651 \%)$ whereas $\mathrm{W}_{55}$ flour $(1.289 \%)$ had highest values due to higher amount of ash or mineral content in potato flour. The ash content increased with increase in the ratio of potato flour in composite flours. The ash content was observed highest for $\mathrm{W}_{55}$ flour $(1.289 \%)$ while lowest for $\mathrm{W}_{85}$ flour $(0.894 \%)$. It was noted that with an increase in the amount of potato flour, the ash content of composite flours increased. Since potato flour was found to have higher ash content $(1.092 \%)$ than those of wheat flour $(0.769 \%)$, rice flour $(0.651 \%)$ and green gram flour $(0.168 \%)$. Similar findings were observed by Kasuhal et al., (2012).

The analysis of variance revealed that the ash content of individual and composite flours was found highly significant at $P \leq 0.05$. The results indicated that different composition of flours influenced the ash content of composite flours. The statistical analysis like SE (d), SE (m), CV and Coefficient of determination (R2) of the flours were calculated and obtained as $0.025,0.018,4.668$ and 0.036 , respectively.

Effect on Acidity: The acidity of composite flours varied with incorporation ratio of other flours. Green gram flour had highest value of acidity $(0.0394 \%)$ whereas rice flour $(0.0142 \%)$ had lowest. The acidity for wheat flour was obtained as $0.0286 \%$ while $0.0292 \%$ for potato flour. The highest value of acidity was obtained for $\mathrm{W}_{55}(0.0266 \%)$ followed by $\mathrm{W}_{85}$ $(0.0228 \%)$ and $\mathrm{W}_{70}(0.0226 \%)$. It seems that the acidity of composite flour was affected by the level of other blended flours. The composite flour acidity was found to be lower than that of acidity of wheat flour. Decreased in the percentage of wheat flour resulted decrease in acidity of composite flours.

The acidity of $\mathrm{W}_{85}$ and $\mathrm{W}_{70}$ were found nonsignificant at $p \leq 0.05$. The acidity of wheat flour, rice flour, green gram flour and potato flour were found little differ at $p \leq 0.05$ level of significance. It is explicit that composition of flours influenced the acidity of composite flours. The statistical analysis like SE (d), SE (m), CV and Coefficient of determination $\left(\mathrm{R}^{2}\right)$ of the flours were calculated and obtained as 0.003, 0.002, 16.645 and 0.070 , respectively.

Effect on pH: The results showed that the $\mathrm{pH}$ of flours ranged from 5.515 to 6.780 (Table 1). The highest $\mathrm{pH}$ was observed for $\mathrm{W}_{55}(6.78)$ while lowest in wheat flour (5.516). The $\mathrm{pH}$ values for rice flour, green gram flour and potato flour were obtained as $6.158,6.25$ and 6.414 respectively. In case of composite flours, the highest $\mathrm{pH}$ was noticed for $\mathrm{W}_{55}(6.78)$ followed by $\mathrm{W}_{70}$ (6.60) and lowest for $\mathrm{W}_{85}$ (6.294). From the study revealed that the $\mathrm{pH}$ of composite flours increased with increase in the level of composition of rice flour, green gram flour and potato flour. It is clear that the $\mathrm{pH}$ of flours except wheat flour was found to be significant at $\mathrm{p} \leq 0.05$ level of significance. The $\mathrm{pH}$ of the composite flours increased with increase in the level of other flours except wheat flour. The $\mathrm{pH}$ of composite flours was significantly affected by wheat flours. The statistical analysis for $\mathrm{pH}$ of flours viz., $\mathrm{SE}(\mathrm{d}), \mathrm{SE}(\mathrm{m})$, $\mathrm{CV}$ and Coefficient of determination $\left(\mathrm{R}^{2}\right)$ were calculated and obtained as $0.182,0.129,4.583$ and 0.172 , respectively.

Effect on Browning index (Optical Density): The browning index (optical density) of different flours is reported in Table 1. The browning index ranged from 0.012 to 0.053 . The maximum value of browning index was observed for $\mathrm{W}_{55}(0.053)$ while the minimum for rice flour (0.012). From Table 1, it is clear that composite flours had higher value of browning index as compared to the individual flour. The browning index of composite flour increased with increase in the level of incorporation proportion of rice flour, green gram flour and potato flour. The browning index for rice, green gram, and potato flour were obtained as 0.012, 0.020 and 0.033 , respectively. Due to enzymatic reaction, discoloration occurred to the product. Browning index of composite flour was affected by the incorporation ratio of potato flour. It is clear that browning index of flours was found to be significant at $\mathrm{p} \leq 0.05$ level of significance. However, wheat flour and rice flour were found insignificant to each other. The increment in browning index of flours may be attributed to enzymatic browning which might have taken place between nitrogenous compound and sugar, nitrogenous compound and organic acids, sugar and organic acids and among organic acids themselves in the presence of enzymes (Srivastava and Kumar, 1993). In general, 
browning index of composite flours increased with the level of composition of rice, green gram and potato flour incorporated with wheat flour. The statistical analysis for browning index of flours viz., SE (d), $\mathrm{SE}(\mathrm{m}), \mathrm{CV}$ and Coefficient of determination $\left(\mathrm{R}^{2}\right)$ of the flours were calculated and obtained as 0.002, 0.001, 10.143 and 0.009 , respectively.

\section{Physical properties of biscuits}

The knowledge of important physical properties such as shape, size, volume, surface area, density, length, thickness, spread ratio, percent spread and mass of biscuits are necessary for designing of baking equipment, packaging materials, handling and storage systems. These properties are also benefitted to calculate the energy and mass balance during baking. The mass, diameter and thickness of biscuits are important to design the mild and cast of the biscuit. Effect on Mass: The variation in mass (g) of biscuits is given in Table 2. The mass per biscuit ranged 7.00 to $8.54 \mathrm{~g}$. The highest mass per biscuit was measured for $\mathrm{W}_{85}$ biscuit $(8.54 \mathrm{~g})$ followed by $\mathrm{W}_{70}(7.77 \mathrm{~g}), \mathrm{W}_{55}$ $(7.02 \mathrm{~g})$ and lowest for wheat flour biscuit $(7.00 \mathrm{~g})$. The study revealed that the mass of composite flour biscuits decreased with increase in the incorporation of rice, green gram and potato flour with wheat flour. The mass of control (wheat flour) biscuits was lowest as compared to composite flour biscuits. The mass of biscuits was affected by the mass of dough taken for making the biscuit.

The biscuits had variation in the initial weight and size of biscuit was prepared by manually. Similar trends were found by Mridula and Wanjari (2006). They were reported that weight of biscuit decreased gradually with increase in proportion of full fat soybeanflour from 5 to 20 percent and decreasing the proportion of wheat flour 100 to 80 percent. The mass of biscuits decreased as the concentration of rice, green gram and potato flour increased in the composite flours. This was probably due to low oil absorption capacity of rice flour and wheat flour. Similar findings were reported by Yadav et al., (2012). The effect of incorporation of rice, green gram and potato flour with wheat flour on mass of biscuit were found to be significant at $\mathrm{p} \leq 0.05$ level of significance. The study was accounted that the mass of biscuit decreased with increase in the incorporation of different flours with wheat flour. The control biscuits were observed lowest mass $(7.00 \mathrm{~g})$ and highest for $\mathrm{W}_{85}$ biscuit $(8.54 \mathrm{~g})$. The statistical study were also revealed that the mass of control biscuits and $\mathrm{W}_{55}$ was not found to be significant at $\mathrm{p} \leq 0.05$ level of significance. The statistical parameters viz., $\mathrm{CD}_{0.05}$, $\mathrm{SE}(\mathrm{d}), \mathrm{SE}(\mathrm{m}), \mathrm{CV}$ and $\mathrm{R}^{2}$ for mass of biscuits were calculated and found as 1.195, $0.542,0.384,11.308$ and 0.015 .

Table 1: Proximate composition of different flours as well as composite flours

\begin{tabular}{|c|c|c|c|c|c|c|c|}
\hline Flours & $\begin{array}{l}\text { Moisture } \\
\text { (\%) }\end{array}$ & $\begin{array}{c}\text { Protein } \\
(\%)\end{array}$ & Fat (\%) & Ash (\%) & Acidity & pH & $\begin{array}{c}\text { Browning } \\
\text { Index }\end{array}$ \\
\hline $\mathrm{W}_{100 \text { (Control) }}$ & $13.28 \pm 1.46$ & $9.64 \pm 0.19$ & $0.83 \pm 0.08$ & $0.77 \pm 0.07$ & $0.03 \pm 0.00$ & $5.51 \pm 0.61$ & $0.01 \pm 0.00$ \\
\hline $\mathrm{W}_{85}$ & $11.67 \pm 0.43$ & $13.45 \pm 0.31$ & $1.21 \pm 0.01$ & $0.89 \pm 0.03$ & $0.023 \pm 0.01$ & $6.29 \pm 0.29$ & $0.02 \pm 0.01$ \\
\hline $\mathrm{W}_{70}$ & $11.34 \pm 0.24$ & $15.15 \pm 0.06$ & $1.34 \pm 0.03$ & $1.08 \pm 0.03$ & $0.022 \pm 0.00$ & $6.60 \pm 0.43$ & $0.04 \pm 0.02$ \\
\hline $\mathrm{W}_{55}$ & $10.93 \pm 0.09$ & $16.84 \pm 1.37$ & $1.39 \pm 0.03$ & $1.29 \pm 0.03$ & $0.027 \pm 0.00$ & $6.78 \pm 0.15$ & $0.05 \pm 0.02$ \\
\hline $\mathrm{R}_{100}$ & $11.22 \pm 0.43$ & $10.06 \pm 0.17$ & $0.98 \pm 0.03$ & $0.65 \pm 0.06$ & $0.014 \pm 0.00$ & $6.16 \pm 0.10$ & $0.01 \pm 0.00$ \\
\hline $\mathrm{G}_{100}$ & $8.05 \pm 0.19$ & $21.04 \pm 0.40$ & $1.23 \pm 0.02$ & $0.17 \pm 0.02$ & $0.039 \pm 0.00$ & $6.25 \pm 0.09$ & $0.02 \pm 0.00$ \\
\hline $\mathrm{P}_{100}$ & $9.60 \pm 0.423$ & $2.14 \pm 0.04$ & $0.33 \pm 0.03$ & $1.09 \pm 0.02$ & $0.029 \pm 0.00$ & $6.41 \pm 0.09$ & $0.03 \pm 0.00$ \\
\hline $\mathrm{CD}_{5 \%}$ & 0.831 & 0.659 & 0.051 & 0.052 & 0.006 & 0.378 & 0.004 \\
\hline $\mathrm{SE}(\mathrm{d})$ & 0.400 & 0.318 & 0.024 & 0.025 & 0.003 & 0.182 & 0.002 \\
\hline $\mathrm{SE}(\mathrm{m})$ & 0.283 & 0.225 & 0.017 & 0.018 & 0.002 & 0.129 & 0.001 \\
\hline $\mathrm{CV}$ & 5.814 & 3.979 & 3.684 & 4.668 & 16.645 & 4.583 & 10.143 \\
\hline $\mathrm{R}^{2}$ & 0.738 & 0.025 & 0.145 & 0.036 & 0.070 & 0.172 & 0.009 \\
\hline $\begin{array}{l}\text { Regression } \\
\text { Equation }\end{array}$ & $\begin{aligned} \mathrm{y}= & -0.657 \mathrm{x}+ \\
& 13.5\end{aligned}$ & $\begin{aligned} \mathrm{y}= & -0.444 \mathrm{x}+ \\
& 14.39\end{aligned}$ & $\begin{aligned} y & =-0.065 x \\
& +1.308\end{aligned}$ & $\begin{aligned} y & =-0.032 \mathrm{x} \\
& +0.98\end{aligned}$ & $\begin{aligned} \mathrm{y}= & 0.000 \mathrm{x}+ \\
& 0.022\end{aligned}$ & $\mathrm{y}=0.077 \mathrm{x}+$ & $\begin{array}{c}\mathrm{y}=0.000 \mathrm{x}+ \\
0.025\end{array}$ \\
\hline
\end{tabular}


Table 2: Physical properties of freshly prepared composite flour biscuits

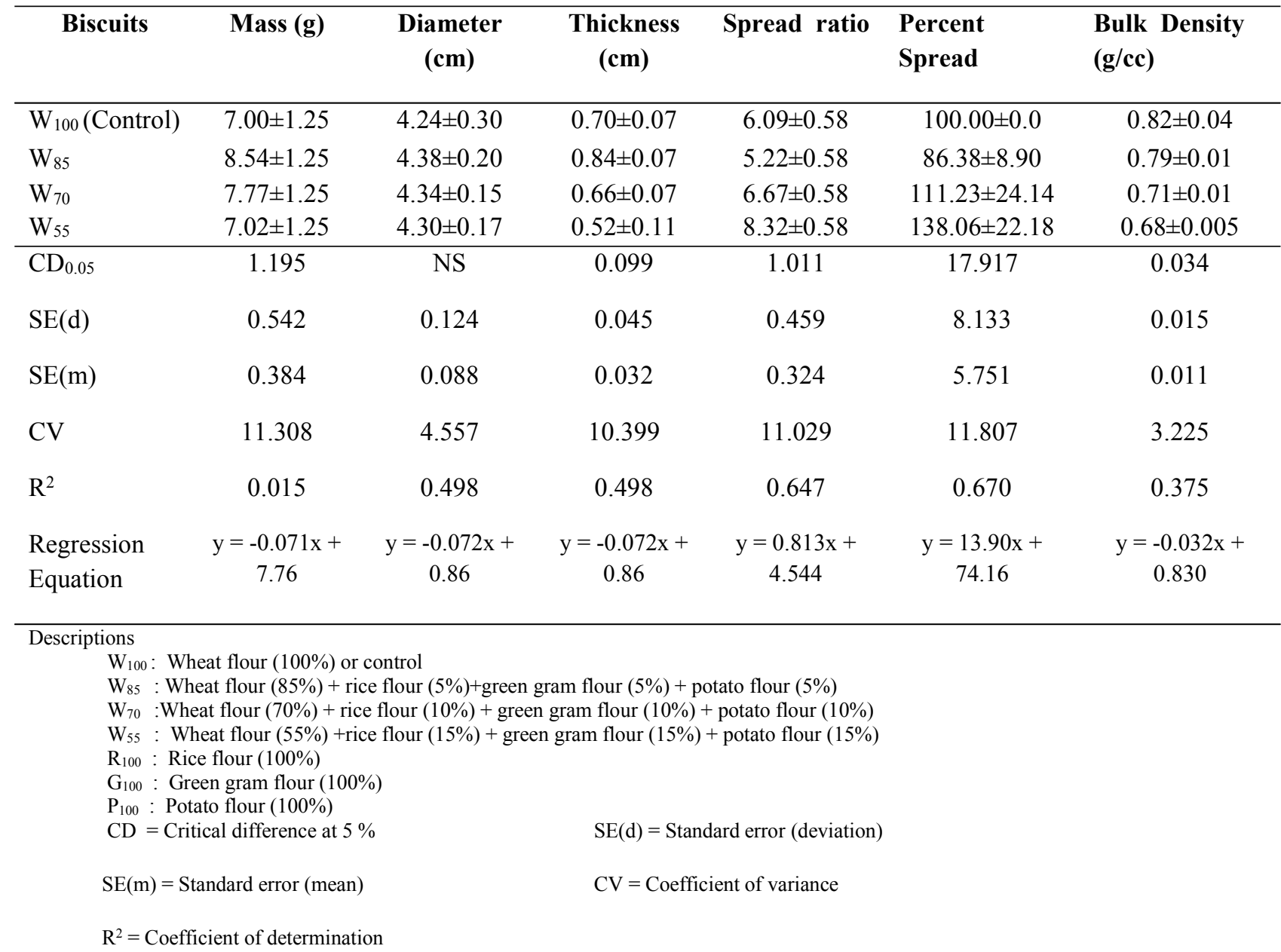

Effect on Diameter: The value of diameter of biscuits ranged 4.24 to $4.38 \mathrm{~cm}$. The highest diameter was observed for $\mathrm{W}_{85}$ biscuits $(4.38 \mathrm{~cm})$ followed by $\mathrm{W}_{70}$ $(4.34 \mathrm{~cm})$ and $\mathrm{W}_{55}(4.30 \mathrm{~cm})$ and lowest for control biscuits $(4.24 \mathrm{~cm})$. It is clear that the diameter of composite flour biscuits had larger as compared to control biscuits. The diameter of composite flour biscuits decreased with increase in the incorporation of rice, green gram and potato flour with wheat flour. Diameter and spread ratio of biscuits are the important parameter used for evaluation the wheat varieties for biscuits making (Nemeth et al., 1994). Larger biscuit diameter and higher spread ratio are considered as the desirable quality attributes (Yamamoto et al., 1996). Similar findings were observed by Yadav et al., (2012). It could be seen that the incorporation of potato, rice and green gram flour with wheat flour had non-significant effect at $p \leq 0.05$ level of significance. The control biscuits had smallest diameter $(4.24 \mathrm{~cm})$ and largest for $\mathrm{W}_{85}$ biscuits $(4.38 \mathrm{~cm})$. The statistical characteristics for variation in diameter of biscuits like $\mathrm{CD}_{0.05}$, $\mathrm{SE}(\mathrm{d}), \mathrm{SE}(\mathrm{m}), \mathrm{CV}$ and $\mathrm{R}^{2}$ were calculated and found as NS, 0.124, 0.088, 4.557 and 0.498 .

Effect on Thickness: Data on the physical parameter like thickness of biscuits as affected by the incorporation of different flours i.e. rice, green gram and potato flour with wheat flour are presented in Table 2. The thickness per biscuit ranged 0.52 to $0.84 \mathrm{~cm}$. The highest thickness per biscuit was measured for $\mathrm{W}_{85}$ biscuit $(0.84 \mathrm{~cm})$ followed by control biscuit $(0.70 \mathrm{~cm}), \mathrm{W}_{70}(0.66 \mathrm{~cm})$ and lowest for $\mathrm{W}_{55}(0.52 \mathrm{~cm})$. From the study revealed that the thickness of biscuits decreased with increase in the incorporation of rice, green gram and potato flour with wheat flour. Highest value of thickness was observed for $\mathrm{W}_{85}$ biscuits as compared to control biscuits. The thickness of biscuits was influenced by the initial mass of the dough ball which was taken for the preparation of biscuits. Decrease 
in diameter and thickness of composite flour biscuits with other flours with wheat flour may be due to dilution of gluten. Similar results were reported by Ajila et al., (2008). The incorporation of different flours with wheat flour on thickness of biscuits were found to be significant at $\mathrm{p} \leq 0.05$ level of significance. The statistical analysis reported that the thickness of biscuits decreased with increase in the incorporation of different flours with wheat flour. Highest value of thickness was measured for $\mathrm{W}_{85}$ biscuits and lowest for $\mathrm{W}_{55}$ biscuits as compared to control biscuits. The statistical parameters of thickness of biscuits like $\mathrm{CD}_{0.05}, \mathrm{SE}(\mathrm{d}), \mathrm{SE}(\mathrm{m}), \mathrm{CV}$ and $\mathrm{R}^{2}$ was calculated as $0.099,0.045,0.032,10.399$ and 0.498 .

Effect on Spread Ratio: The spread ratio is the ratio of diameter to thickness of biscuits. The variation in spread ratio for biscuits is given in Table 2 . The spread ratio of biscuits ranged 5.224 to 8.320 . The highest spread ratio was evaluated for $\mathrm{W}_{55}$ biscuits (8.320) followed by $\mathrm{W}_{70}$ (6.676), $\mathrm{W}_{85}$ (5.224) and lowest for control biscuits (6.092). The results indicated that the incorporation of different flours with wheat flour increased the spread ratio of biscuits. Spread ratio of $\mathrm{W}_{85}$ biscuit was found lower than control biscuits but higher for $\mathrm{W}_{70}$ and $\mathrm{W}_{55}$ biscuits. Results were also revealed that the spread ratio of composite flour biscuits increased with decrease in the incorporation of wheat flour with others flours. It is depicted that spread ratio is mostly influenced by the diameter and thickness of biscuits. Spread ratio and percent spread decreased with addition of rice, green gram and potato flour. Rababah et al., (2006) reported the reduction in spread ratio when chickpea, broad bean and isolate soy protein were substituted for wheat flour in biscuits. It was observed that the spread ratio of $\mathrm{W}_{55}$ biscuit was found to be significant as compared to control biscuits at $\mathrm{p} \leq 0.05$ level of significance. Spread ratio of other biscuit samples was found to be insignificant to each other. Spread ratio of the composite flour biscuits increased with increase in the incorporation of different flours. Spread ratio of $\mathrm{W}_{85}$ biscuits had lower than control biscuits at $\mathrm{p} \leq 0.05$ level of significance. The statistical characteristics for spread ratio of biscuits viz., $\mathrm{CD}_{0.05}, \mathrm{SE}$ (d), SE (m), CV and $\mathrm{R}^{2}$ was elaborated as 1.011, 0.459, $0.324,11.029$ and 0.647 , respectively.

Effect on Percent Spread: The experimental data for variation in percent spread of biscuits is shown in Table 2 . The percent spread of biscuits varied 86.378 to 138.058 . The highest score of percent spread were observed for
$\mathrm{W}_{55}$ biscuits (138.058) followed $\mathrm{W}_{70}$ (111.228), control biscuits (100.00) and lowest for $\mathrm{W}_{85}$ biscuits (86.378). The study revealed that the percent spread of biscuit increased with increase in the incorporation of different flours with wheat flour. The percent spread of biscuits increased with decrease in the incorporation of wheat flour. Percent spread of biscuits was influenced by the thickness and diameter of biscuits. Adair et al., (2001) found that mung bean paste incorporation reduced cookie spread at all the level of substitutions $(25,50,75$ and $100 \%$ ) of peanut butter which was not similar to present study. Mandal et al., (2004) reported that incorporation of 25 percent green gram flour in the formulation of biscuit improved height, diameter, spread ratio, colour, texture and flavour. Study revealed that the percent spread of biscuits were affected insignificantly at $p<0.05$ level of significance. The spread ratio of $\mathrm{W}_{55}$ biscuit was found to be significant as compared to control biscuits while other was found insignificant to each other. The spread ratio of biscuits was increased insignificantly with increase in the incorporation of rice, green gram and potato flour with wheat flour. The statistical parameters for spread ratio of biscuits like $\mathrm{CD}_{0.05}$, SE (d), SE (m), CV and $\mathrm{R}^{2}$ were calculated as $17.917,8.133,5.751,11.807$ and 0.670 (Table 2).

Effect on Bulk density: The variation in bulk densities of biscuits are reported in Table 2, which shows the effect of incorporation of rice, green gram and potato flours with wheat flour. Bulk densities of biscuits ranged 0.6782 to $0.8160 \mathrm{~g} / \mathrm{cc}$. The highest bulk density was reported for control biscuits $\left(0.8160 \quad(\mathrm{~g} / \mathrm{cc})\right.$ followed by $\mathrm{W}_{85}$ $(0.7999 \mathrm{~g} / \mathrm{cc}), \mathrm{W}_{70}(0.7079 \mathrm{~g} / \mathrm{cc})$ and lowest for $\mathrm{W}_{55}$ biscuits $(0.6782 \mathrm{~g} / \mathrm{cc})$. It was also noticed that level of incorporation of different flours was influenced the bulk density of biscuits. From Table 2, it was observed that the bulk densities among all biscuit samples decreased with increase in the incorporation of rice, green gram and potato from with wheat flour while decreased with decrease in the proportions of wheat flour in composite flours. Hence, bulk density of biscuits depends on the particle size of incorporating flours which reduced by coarse size of potato flours in biscuits. Akubor and Obiegbuna (1999) reported that bulk density of sample could be used in determining its packaging requirements as this related to the load the sample can be carry it allowed to rest directly on one another. The density is often noted as an important quality parameter in biscuit making, in particular for predicting crunchiness 
(Bartalucci and Launay, 2000). Lower density is often suggested as a quality index for biscuits (Fustier et al., 2009). Study revealed that the bulk density of biscuits was found to be significant at $p \leq 0.05$ level of significance. The bulk density of $\mathrm{W}_{70}$ and $\mathrm{W}_{55}$ biscuits were found to be significant except $\mathrm{W}_{85}$ as compared to control biscuits. It is clear the bulk density decreased significantly with increase in the incorporation of different flours with wheat flour. Highest bulk density was found for control biscuits while lowest for $\mathrm{W}_{55}$ biscuits at $\mathrm{p} \leq 0.05$ level of significance. The statistical characteristics for bulk density of biscuits like $\mathrm{CD}_{0.05}, \mathrm{SE}(\mathrm{d}), \mathrm{SE}(\mathrm{m}), \mathrm{CV}$ and $\mathrm{R}^{2}$ was calculated as $0.034,0.015,0.011,3.22507$ and 0.375 (Table 2).

\section{Conclusions}

Size and shape are important physical parameters which is used to screen, grade and quality control of foods. A knowledge of physical properties constitute important and engineering data in design of transportation models, machines, storage structure and racks, processing, packaging and handling equipments and materials and also in evaluating and retaining the quality of final end products. Such basic information should be of value not only to engineers but also food technologist, processors, bakers, and other scientists who may exploit these properties and find new uses and ideas. The physical properties of these biscuits were observed. The mass, diameter, thickness and bulk densities decreased whereas spread ratio and percent spread increased with increasing the level of incorporation of other flours.

\section{References}

1. Adair, M., Knight, S. and Gates, G. (2001). Acceptability of PB cookies prepared using mung bean paste as fat ingredient substitute. J. Am. Diet Assoc. 101:467-469.

2. Adeyemi, A., Komolafe, A and Akindele, A.O. (1989). Properties of steam blanched maize flour as a constituents of weaning foods. J. Food Process. Pres. 13:133-144.

3. Ajila, C.M., Leelavathi, K. and Rao, U.J.S.P. (2008). Improvement of dietary fibre content and antioxidant properties in soft dough biscuits with the incorporation of mango peel powder. J. Cereal Sci., 48:319-326
4. Akubor, P.I. and Obiebuna, J.E. (1999). Certain chemical and functional properties of ungerminated and germinated millet flour. J. Food Sci. Technol. 36:241-243.

5. Akubor, P.I. (2007). Chemical, functional and cookie baking properties of soybean/maize flour blends. J. Food Sci. Technol., 44(6): 619-622.

6. Anjum, F.M., I. Ahmad, M.S. Butt, M.A. Sheikh and I. Pasha. (2005). Amino acid composition of spring wheats and losses of lysine during chapati baking. J. Food Comp. Anal. 18: 523-532.

7. AOAC (2000). Official methods of analysis of AOAC International (1 $17^{\text {th }}$ ed.). Gaitherburg. USA: AOAC International Inc.

8. Bakle, A. and Vickers Z (2007). Consumer liking of refined and whole wheat breads. J. Food Sci. 72: S473-S480.

9. Bartolucci, J.C. and Launay, B. (2000). Stress relaxation of wheat flour doughs following bubble inflation or lubricated squeezing flow and its relation to wheat flour quality. In J.D. Schofield (ed), wheat structure, biochemistry and functionality (pp. 323-331), Cambridge: The Royal Society of Chemistry.

10. Bassi, R.K. and De, S. (1973). Protein-enriched milk biscuits. J. Food Sci. Technol. 10:181-183

11. Chandra, S., Singh, S. and Kumari, D. (2014). Evaluation of functional properties of composite flours and sensorial attributes of composite flour biscuits. J. Food Sci. Technol. DOI:10.1007/s13197-014-1427-2

12. Dewettinck, K., Van Bockstaele, F., Kuhne, B., Van de Walle., Courtens, T. and Gellynck, X. (2008). Nutritional value of bread: Influence of processing, food interaction and consumer perception. Rev. J. Cereal Sci., 48:243-257.

13. Eneche, E.H. (1999). Biscuit making potential of millet (Pigeon pea flour blends). Plants Foods for Human Nutrition. 54(1):21-27.

14. Fustier, P., Casteigne, F. Turgeon, S.L. and Biliaderis, C.G. (2009). Impact of endogenous constituents from different flour milling streams on dough rheology and semi-sweet biscuit making potential by partial substitution of a commercial soft wheat flour. LWT-Food Sci. Technol. 42:363-371.

15. Gallagher, E., Kenny, S. and Arendt, E.K. (2005). Impact of dairy protein powder on 
biscuit quality. European Food Res. Technol. 221:237-243

16. Gandhi, A.P., Nachiket, K., Jolly, K., Srivastav, D.C., Parihar, V.C. and Raghunadh, P. (2001). Effect of incorporation of defatted soy flour on the quality of sweet biscuits. J. Food Sci. Technol. 38:502-503.

17. Guillon, F. and Champ, M. (1996). Grain Legunes and transit in humans. Grain Legumes AEP 11: 18-21.

18. Hegazy, N.A. and Faheid, S.M. (1990). Rheological and sensory characteristics of dough and cookies based on wheat, soy bean, chick pea and lupin flour. Nahrung, 34: 835-841.

19. Hooda, S. and Jood, S. (2005). Organoleptic and nutritional evaluation of wheat biscuits supplemented with untreated and treated fenugreek flour. Food Chem. 90:427-435.

20. Hugo, L.F., Rooney, L.W. and Taylor, J.R.N. 2000. Malted sorghum as a functional ingredient in composite bread. Cereal Science 79(4): 428432.

21. Hung, S.C. and J.F. Zayas. 1991. Emulsifying capacity and emulsion stability of milk proteins and corn germ protein flour. J. Food Sci. 56 (5): 1216-1218, 1223.

22. Iqbal, A., I.A. Khalil, N. Ateeq and M.S. Khan. 2006. Nutritional quality of important food legumes. Food Chem. 97: 331-335.

23. Jideani, V. and Onwubali, F. (2009). Optimization of wheat-sprouted soybean flour bread using response surface methodology. Afr. J. Biotechnol. 8(22): 6364-6373.

24. Kaushal, P., Kumar, V. and Sharma, H.K. (2012). Comparative study of physico-chemical, functional, anti-nutritional and pasting properties of taro (Colocasiaesculenta), rice (Oryza sativa), pegion pea (Cajanus cajan) flour and their blends. LWT-Food Sci. Technol. 48:59-68.

25. Khaliduzzaman., Sham-Ud-Din, M. and Islam, M.N. (2010). Studies on the preparation of chapatti and biscuits supplemented with potato flour. J. Bangladesh Agric. Univ., 8(1):153-160.

26. Laguna, L., Salvador, A., Sanz, T., Fiszman, S.M. (2011). Performance of a resistant starch rich ingredient in the baking and eating quality of short-dough biscuits. LWT - Food Sci. and Technol., 44:737-746.
27. Mandal, S., Singh, G. and Agrawal, P. (2004). Development of green gram fortified biscuits. Indian baker.3:31-38

28. Marcello, D. and Gius, C. (1997). Legume seeds: protein content and nutritional value. Field Crops Res. 53: 31-45.

29. Michaelsen, K.F. and Henrik, F. (1998). Complementary feeding: A global perspective. Nutr. 14(10): 763-766.

30. Mishra, P., Usha, M. S. and Singh, S. (1991). Bengal gram flour-Wheat flour blends: chemical, archeological and baking characters. J. Food. Sci. Technol. 28 (2): 89.

31. Mridula, D. and Wanjari, O.D. (2006). Effect of incorporation of full fat soy flour on quality of biscuits. Bev. Food World. 33(8):35-36

32. Myer, R.O., J.H. Brendemuhl and R.D. Barnett. 1996. Crystalline lysine and threonine supplementation of soft red winter wheat or Triticale, low protein diets for growing-finishing swine. Anim. Sci. 74: 577-583.

33. Nemeth, L.J., Williams, P.C. and Bushuk, W. (1994). A comparative study of the quality of soft wheat from Canada, Australia and United States. Cereal Foods World. 691-699.

34. Njintang, Y.N., Mbofung, C.M.F., Balaamm F., Kitissou, P. and Scher, J. (2007). Effect of taro (Colocasia esculenta) flour addition on the functional alveographic properties of wheat flour and dough. J. Sci. Food Agri. 88(2):273-279.

35. Okaka, J.C. and Potter, N.N. (1977). Functional and storage properties of cow pea-wheat flour blends in bread making. J. Food Sci. 42: 828-833.

36. Olsen, R.E. (1975). Protein-calorie nutrition. New York, USA: Academic Press.

37. Patel, M. M and Rao, Venkateswara G. (1995). Effect of untreated, roasted and germinated black gram (Phaseolus mungo L.) Flours on the physicochemical and biscuit (cookie) making characteristics of soft wheat flour. J. Cereal Sci., 22: 285-291.

38. Pogna, N.E., R. Redaelli, T. Dachkevitch, A. Curioni and A. Dal Belin Peruffo. 1994. Genetics of wheat quality and its improvement by conventional and biotechnological breeding. In: Bushuk, W. and V.F. Rasper (eds.) Wheat production, properties and quality. Chapman Hall, London. 
39. Rababah, T.M., Al-Mahasneh, M.A. and Ereifej, K.I. (2006). Effect of chickpea, broad bean or isolate soy protein (ISP) additions on the physicchemical and sensory properties of biscuits. J. Food Sci., 71:438-442.

40. Rajput, L.P., Haridas Rao, P. and Shurpalekar, S.R. (1988). Use of unconventional sources in high protein biscuits. J. Food Sci. Technol. 25:31-34

41. Ranganna, S. (2001). Handbook of analysis and quality control for fruit and vegetable products ( $2^{\text {nd }}$ ed). Tata McGraw Hill Pub. Co. Ltd. New Delhi.

42. Rao, B.R., Rajor, R.B. and Patil, G.R. (1984). Formulation of protein-rich biscuits from jowar, soybean and skim milk. J. Food Sci. Technol. 21:236-239

43. Rao, P.H. and Shurpalekar, S.R. (1976). Utilization of milo in bakery products. J. Food Sci. Technol. 13:293-299.

44. Seevaratnam, V., Bonumathi, P., Premalatha, M.R., Sundaram, S.P. and Arumugam, T. (2012). Studies on the preparation of biscuits incorporated with potato flour. World. J. Dairy food Sci., 7(1):79-84.

45. Shittu, T.A., Raji, A. O. and Sanni, A.O. 2007. Effect of baking time and temperature on some physicalo properties of bread loaf. Food Res. Internat. 40(2): 280-290.
46. Siddhuraju P, Vijayakumari K, Janardhanan K (1996). Chemical composition and protein quality of the little known legume, velvet bean (Mucuna pruriens). J. Agric. Food Chem. 44: 2636-2641.

47. Singh R, Singh G, Chauhan G.S. (1996). Effect of incorporation of defatted soy flour on the quality of biscuits. J. Food Sci. Technol.,33: 355-357.

48. Singh, R., Singh, G. and Chauhan, G.S. (2000). Development of soy-fortified biscuits and shelf life studies. J. Food Sci. Technol. 37:300-303.

49. Sirtori, C.R. and Lovati MR (2001). Soy proteins and cardiovascular disease. Corr. Atheroscler. Rep. 3: 47-53.

50. Srivastava, R.P. and Kumar, S. (1993). Fruits and Vegetables Preservation: Principles and Practices. International Book Distributing Co., Lucknow (UP).

51. Tyagi, S.K., Manikantan, M.R., Oberoi, H.S. and Kaur, G. (2007). Effect of mustard flour incorporation on nutritional, textural and organoleptic characteristics of biscuits. J. Food Eng. 80:1043-1050.

52. Yadav, R.B., Yadav, B.S. and Dhull, Nisha (2012). Effect of incorporation of plantain and chickpea flours on the quality characteristics of biscuits. J. Food Sci. Technol. 49(2):207-213

53. Yamamoto, H., Worthington, S.T., Hou, G. and Ng, P.K.W. (1996). Rheological properties and baking quality of selected soft wheat in United States. Cereal Chem. 73:215-221 